\title{
Diabetogenic Action of Streptozotocin: Relationship of Dose to Metabolic Response
}

\author{
Alain Junod, André E. Lambert, Werner Stauffacher, and \\ Albert E. RENold \\ From the Institut de Biochimie Clinique, University of Geneva, \\ Geneva, Switzerland
}

\begin{abstract}
A B S TRACT The relationship between the dose of intravenously administered streptozotocin (a $N$-nitroso derivative of glucosamine) and the diabetogenic response has been explored by use of the following indices of diabetogenic action: serum glucose, urine volume, and glycosuria, ketonuria, serum immunoreactive insulin (IRI), and pancreatic IRI content. Diabetogenic activity could be demonstrated between the doses of 25 and 100 $\mathrm{mg} / \mathrm{kg}$, all indices used showing some degree of correlation with the dose administered. Ketonuria was only seen with the largest dose, $100 \mathrm{mg} / \mathrm{kg}$. The most striking and precise correlation was that between the dose and the pancreatic IRI content $24 \mathrm{hr}$ after administration of the drug, and it is suggested that this represents a convenient test system either for both related and unrelated beta cytotoxic compounds or for screening for modifying agents or antidiabetic substances of a novel type. Ability to produce graded depletion of pancreatic IRI storage capacity led to an analysis of the relationship between pancreatic IRI content and deranged carbohydrate metabolism. Abnormal glucose tolerance and insulin response were seen when pancreatic IRI was depleted by about one-third, while fasting hyperglycemia and gross glycosuria occurred when the depletion had reached twothirds and three-quarters, respectively. The mild yet persistent anomaly produced by the lowest effective streptozotocin dose, $25 \mathrm{mg} / \mathrm{kg}$, exhibits characteristics resembling the state of chemical diabetes in humans and might thus warrant further study as a possible model. Finally, the loss of the diabetogenic action of streptozotocin by pretreatment with nicotinamide was confirmed and was shown to be a function of the relative doses of nicotinamide and streptozotocin and of the interval between injections.
\end{abstract}

Dr. A. E. Lambert is Chargé de Recherches of the Fonds National de la Recherche Scientifique, Belgium.

Received for publication 12 June 1968 and in revised form 18 July 1969.

\section{INTRODUCTION}

Previous reports from this laboratory have dealt with a preliminary characterization (1) of the diabetogenic action of streptozotocin discovered by Rakieten, Rakieten, and Nadkarni (2), as well as with a detailed morphologic evaluation ${ }^{1}$ of the ultrastructural alterations of pancreatic $\beta$-cells brought about by the administration of this agent. Contrary to the suggestions of others $(3,4)$, it was shown that the diabetogenic action of streptozotocin results primarily from its highly specific cytotoxic action on the $\beta$-cells of the islets of Langerhans with rapid and irreversible necrosis (1). It was further suggested that the intensity of the damage to the $\beta$-cells could be graded according to the dosage used. In the present study, we report on a detailed analysis of the relationship between streptozotocin dosage and the resulting metabolic alterations, including blood glucose and serum immunoreactive insulin (IRI) levels and pancreatic IRI content. The results provide further confirmation of the highly specific nature of the streptozotocin action on $\beta$-cells and of the possibility of utilizing this agent for the production of diabetes of graded severity. Recent results confirming the loss of the diabetogenic action of streptozotocin by pretreatment with nicotinamide (5) are also reported. It is of interest that streptozotocin is now known to be a $N$-nitroso derivative of glucosamine (6).

\section{METHODS}

The experimental animals were male white Wistar rats, bred in our laboratory, weighing between 170 and $230 \mathrm{~g}$. They were fasted for $16 \mathrm{hr}$ before the injection of streptozotocin into the saphenous vein, under light ether anesthesia. Subsequently, those animals which were to be sacrificed $1-10 \mathrm{hr}$ after the injection continued to fast, while those which were to be sacrificed later were placed in metabolic cages with free access to water and laboratory chow pellets.

\footnotetext{
${ }^{1}$ Orci, L., R. Pictet, A. Junod, A. E. Renold, and C. Rouiller. In preparation.
} 
They too were fasted again, $16 \mathrm{hr}$ before they were sacrificed.

Streptozotocin (lots $4621 \mathrm{HKJ} 126 \mathrm{D}$ and 6742 DEG 30-5, a gift from The Upjohn Company, Kalamazoo, Mich.) was dissolved in acidified $0.9 \%$ saline ( $\mathrm{pH} 4.5)$ immediately before injection (1). Injection volume was $0.5 \mathrm{ml} / 200 \mathrm{~g}$ body weight, the concentration of streptozotocin was adjusted according to the desired dose. Control animals, injected with acidified saline alone, were included in each experiment and sacrificed at the same time intervals as experimental animals. This treatment was without any effect on pancreatic and serum IRI. Accordingly, the results of control experiments are reported only where direct comparison is desirable and and at 0 -time in experiments concerned with the time sequence of metabolic events. The importance of rapidly adjusting and maintaining the $\mathrm{pH}$ of the streptozotocin solutions around 4.5 is again emphasized. The animals, by groups of from four to twelve, were sacrificed by decapitation after light intraperitoneal pentobarbital anesthesia. Blood was collected from decapitated animals and was allowed to clot at room temperature for $2 \mathrm{hr}$. Serum was then separated by centrifugation and kept at $-20^{\circ} \mathrm{C}$ for further measurements. About two-thirds of the pancreas, free from fat and ganglia, was also kept at $-20^{\circ} \mathrm{C}$ until subjected to acidethanol extraction according to the method of Scott and Fisher (7). Serum glucose was measured with $o$-toluidine (8), whereas both serum and pancreas IRI were estimated by a slight modification of the methods of Hales and Randle (9), and Morgan and Lazarow (10). Rats were weighed and their urine, accumulated for 24-hr periods, was collected weekly. Glycosuria was determined semiquantitatively with Clinitest (The Ames Co., Elkhart, Ind.) or Tes-Tape (Eli Lilly \& Co., Indianapolis, Ind.) on suitably diluted urine, while ketonuria was estimated with Acetest tablets (Ames).

For the measurement of glucose tolerance, the animals were fasted for $16 \mathrm{hr}$ before the test, which was performed either before or $1 \mathrm{wk}$ after the injection of streptozotocin; $3 \mathrm{~g}$ of glucose $/ \mathrm{kg}$ body weight were given as a $20 \%$ solution by gastric tube. Blood samples $(0.4 \mathrm{ml})$ were obtained from the tail before the test and again after 30,60 , and $120 \mathrm{~min}$. They were collected into plastic microfuge tubes and immediately centrifuged for $2 \mathrm{~min}$ in the Beckman Spinco microfuge at $15,000 \mathrm{rpm}$. After $4 \mathrm{hr}$, the animals were sacrificed by decapitation after light intraperitoneal pentobarbital anesthesia, blood was collected, and the tail and body of the pancreas were dissected free from fat and ganglia and immediately stored at $-20^{\circ} \mathrm{C}$. After centrifugation, plasma was collected separately for glucose and IRI estimations and kept at $-20^{\circ} \mathrm{C}$ until used. Nicotinamide (a gift from Hoffmann-La Roche and Co., Basel, Switzerland) was dissolved in sterile $0.9 \% \mathrm{NaCl}$ for intraperitoneal administration at various times before the injection of streptozotocin. The animals were sacrificed $24 \mathrm{hr}$ after the streptozotocin injection.

\section{RESULTS}

With the intravenous dose of $65 \mathrm{mg} / \mathrm{kg}$ (Fig. 1 and Table I), a clear-cut increase of blood glucose levels was observed at the 2nd and 4th $\mathrm{hr}$ without any parallel increase of serum IRI; at the $7 \mathrm{th} \mathrm{hr}$, there was severe hypoglycemia associated with a significantly $(P<0.001)$ increased serum IRI, but, at this time, there was no concomitant decrease of pancreatic IRI content. After $10 \mathrm{hr}$, several of the fasted animals died, probably from hypoglycemia, whereas such deaths were not noted in animals fed after streptozotocin injection. After $24 \mathrm{hr}$, the diabetic state became evident, characterized by gross polyuria, glycosuria, hyperglycemia, and a fall in the pancreatic IRI content from 1.8 to $0.09 \mathrm{mU} / \mathrm{mg}$, i.e., $5 \%$ of the initial value; the levels of serum IRI, although similar to those of the fasted controls, were abnormally low when related to the coexisting hyperglycemia. As judged by the same indices, the metabolic state remained essentially unchanged after 7 and 28 days, apart from a further decrease of the pancreatic IRI content after 1 month and progressively increasing urine volumes over the 1st wk. Genital fat pads, as well as mesenteric and subcutaneous fat which had already atrophied after 7 days, were virtually absent after 28 days. The weight curve remained flat (Fig. 2). There was no measurable ketonuria at any time.

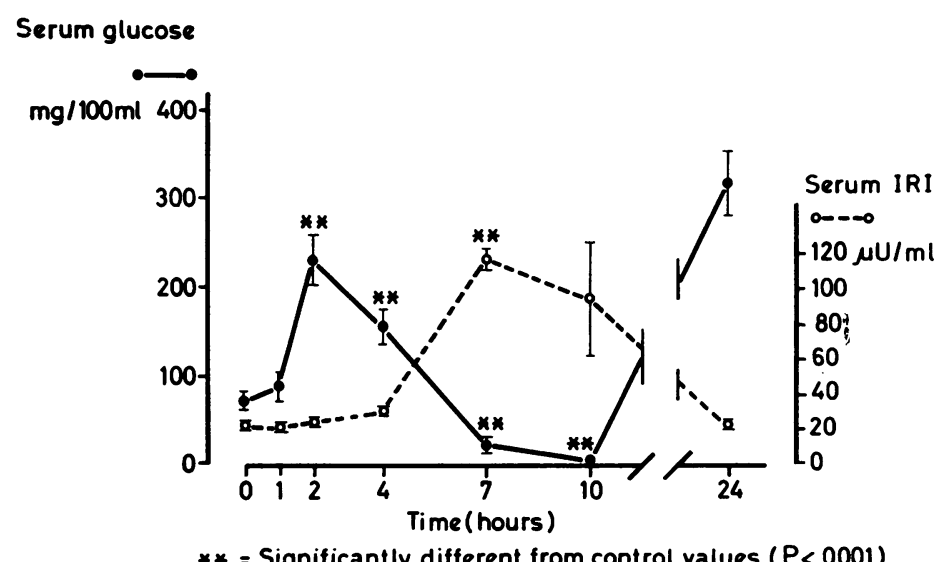

Figure 1 Effects of the intravenous (i.v.) injection of $65 \mathrm{mg} / \mathrm{kg}$ streptozotocin on serum glucose and immunoreactive insulin (IRI) of rats fasted $16 \mathrm{hr}$ (mean \pm SEM). 
TABLE I

Effects of Various Intravenous Doses of Streptozotocin in Rats Fasted $16 \mathrm{hr}$ (Mean $\pm S E M$ )

\begin{tabular}{|c|c|c|c|c|c|c|c|c|c|c|c|c|c|}
\hline \multirow[b]{2}{*}{ Dose } & \multirow[b]{2}{*}{ Measurement } & \multicolumn{12}{|c|}{ Time after the i.v. injection of streptozotocin } \\
\hline & & $0 \mathrm{hr}$ & Ir (n) & $1 \mathrm{~h}$ & ar (n) & $7 \mathrm{hr}$ & ar (n) & $24 \mathrm{hr}$ & (n) & 7 day & $(\mathrm{n})$ & 28 days & (n) \\
\hline $100 \mathrm{mg} / \mathrm{kg}$ & $\begin{array}{l}\text { Serum glucose, } m g / 100 m l \\
\text { Serum IRI, } \mu U / m l \\
\text { Pancreatic IRI, } m U / m g\end{array}$ & $\begin{array}{l}77.4 \\
24 \\
1.85\end{array}$ & $\begin{array}{l} \pm 4(17) \\
\pm 2 \\
\pm 0.08\end{array}$ & $\begin{array}{c}165.6 \\
15.2 \\
1.91\end{array}$ & $\begin{array}{l} \pm 12.7(5) \\
\pm 1 \\
\pm 0.27\end{array}$ & $\begin{array}{l}25.7 \\
90 \\
1.15\end{array}$ & $\begin{array}{l} \pm 8.4(6) \\
\pm 20 \\
\pm 0.24\end{array}$ & $\begin{array}{l}346.6 \\
11.3 \\
0.042\end{array}$ & $\begin{array}{l} \pm 16(6) \\
\pm 0.4 \\
\pm 0.01\end{array}$ & & & & \\
\hline $65 \mathrm{mg} / \mathrm{kg}$ & $\begin{array}{l}\text { Serum glucose, } m g / 100 m l \\
\text { Serum IRI, } \mu U / m l \\
\text { Pancreatic IRI, } m U / m g\end{array}$ & & & $\begin{array}{l}86.1 \\
22.7 \\
1.34\end{array}$ & $\begin{array}{l} \pm 17(6) \\
\pm 1.2 \\
\pm 0.18\end{array}$ & $\begin{array}{r}24 \\
116.3 \\
2.02\end{array}$ & $\begin{array}{l} \pm 7(10) \\
\pm 13 \\
\pm 0.14\end{array}$ & $\begin{array}{r}330 \\
21.5 \\
0.09\end{array}$ & $\begin{array}{l} \pm 37(8) \\
\pm 2 \\
\pm 0.02\end{array}$ & $\begin{array}{l}209.6 \\
25.2 \\
0.083\end{array}$ & $\begin{array}{l} \pm 47(5) \\
\pm 2.2 \\
\pm 0.02\end{array}$ & $\begin{array}{c}262.2 \\
23.7 \\
0.035\end{array}$ & $\begin{array}{l} \pm 62(6) \\
\pm 2.3 \\
\pm 0.006\end{array}$ \\
\hline $55 \mathrm{mg} / \mathrm{kg}$ & $\begin{array}{l}\text { Serum glucose, } m g / 100 m l \\
\text { Serum IRI, } \mu U / m l \\
\text { Pancreatic IRI, } m U / m g\end{array}$ & & & $\begin{array}{r}112.6 \\
22.7 \\
2.1\end{array}$ & $\begin{array}{l} \pm 12(6) \\
\pm 2 \\
\pm 0.18\end{array}$ & $\begin{array}{l}22.7 \\
86.6 \\
1.95\end{array}$ & $\begin{array}{l} \pm 7(6) \\
\pm 20 \\
\pm 0.23\end{array}$ & $\begin{array}{l}340 \\
27.8 \\
0.131\end{array}$ & $\begin{array}{l} \pm 79(6) \\
\pm 1.3 \\
\pm 0.036\end{array}$ & $\begin{array}{l}204 \\
38 \\
0.11\end{array}$ & $\begin{array}{l} \pm 51(5) \\
\pm 11 \\
\pm 0.016\end{array}$ & $\begin{array}{c}333.7 \\
19.8 \\
0.056\end{array}$ & $\begin{array}{l} \pm 25(6) \\
\pm 0.6 \\
\pm 0.013\end{array}$ \\
\hline $45 \mathrm{mg} / \mathrm{kg}$ & $\begin{array}{l}\text { Serum glucose, } m g / 100 m l \\
\text { Serum IRI, } \mu U / m l \\
\text { Pancreatic IRI, } m U / m g\end{array}$ & & & $\begin{array}{r}136.5 \\
27.7 \\
2.0\end{array}$ & $\begin{array}{l} \pm 16(6) \\
\pm 3.7 \\
\pm 0.37\end{array}$ & $\begin{array}{r}69.7 \\
129.7 \\
1.93\end{array}$ & $\begin{array}{l} \pm 17(6) \\
\pm 54 \\
\pm 0.2\end{array}$ & $\begin{array}{c}281 \\
38.4 \\
0.29\end{array}$ & $\begin{array}{l} \pm 55(5) \\
\pm 2.2 \\
\pm 0.08\end{array}$ & $\begin{array}{l}146 \\
24.3 \\
0.22\end{array}$ & $\begin{array}{l} \pm 13(6) \\
\pm 1.6 \\
\pm 0.03\end{array}$ & $\begin{array}{c}223.4 \\
23.1 \\
0.15\end{array}$ & $\begin{array}{l} \pm 18(7) \\
\pm 2.7 \\
\pm 0.01\end{array}$ \\
\hline $35 \mathrm{mg} / \mathrm{kg}$ & $\begin{array}{l}\text { Serum glucose, } m g / 100 m l \\
\text { Serum IRI, } \mu U / m l \\
\text { Pancreatic IRI, } m U / m g\end{array}$ & & & $\begin{array}{r}121.8 \\
25.7 \\
1.9\end{array}$ & $\begin{array}{l} \pm 22.8(6) \\
\pm 1.5 \\
\pm 0.11\end{array}$ & $\begin{array}{l}70.3 \\
73 \\
2.05\end{array}$ & $\begin{array}{l} \pm 14.5(6) \\
\pm 9 \\
\pm 0.17\end{array}$ & $\begin{array}{l}191.7 \\
65 \\
0.72\end{array}$ & $\begin{array}{l} \pm 16(6) \\
\pm 12 \\
\pm 0.16\end{array}$ & $\begin{array}{r}130.5 \\
48.8 \\
0.37\end{array}$ & $\begin{array}{l} \pm 12.8(6) \\
\pm 9.9 \\
\pm 0.11\end{array}$ & $\begin{array}{c}174.7 \\
44 \\
0.42\end{array}$ & $\begin{array}{l} \pm 29(6) \\
\pm 4.2 \\
\pm 0.16\end{array}$ \\
\hline $25 \mathrm{mg} / \mathrm{kg}$ & $\begin{array}{l}\text { Serum glucose, } m g / 100 m l \\
\text { Serum IRI, } \mu U / m l \\
\text { Pancreatic IRI, } m U / m g\end{array}$ & & & $\begin{array}{c}100.3 \\
23.0 \\
1.72\end{array}$ & $\begin{array}{l} \pm 15(6) \\
\pm 0.2 \\
\pm 0.17\end{array}$ & $\begin{array}{l}87.8 \\
16 \\
1.67\end{array}$ & $\begin{array}{l} \pm 7(6) \\
\pm 1.3 \\
\pm 0.29\end{array}$ & $\begin{array}{r}116.3 \\
21.2 \\
1.22\end{array}$ & $\begin{array}{l} \pm 11.6(6) \\
\pm 2.4 \\
\pm 0.2\end{array}$ & $\begin{array}{l}111.8 \\
17 \\
1.38\end{array}$ & $\begin{array}{l} \pm 6(6) \\
\pm 2 \\
\pm 0.13\end{array}$ & & \\
\hline
\end{tabular}

IRI, immunoreactive insulin.

By comparison with $65 \mathrm{mg} / \mathrm{kg}, 100 \mathrm{mg} / \mathrm{kg}$ (Table I) resulted in earlier appearance of the initial hyperglycemia, a more pronounced decrease of pancreatic IRI content after 7 and $24 \mathrm{hr}$, and a more acute and progressive diabetic state, i.e., appearance of ketonuria within the first $24 \mathrm{hr}$ and death of most of the animals within 2-3 days. The administration of insulin (10-15 U/kg Novo lente subcutaneously) prevented death and led to the disappearance of ketonuria.

The effects of $55 \mathrm{mg} / \mathrm{kg}$ streptozotocin were very nearly the same as those of $65 \mathrm{mg} / \mathrm{kg}$, whereas the intravenous injection of $45 \mathrm{mg} / \mathrm{kg}$ was followed by a diabetic state of lesser severity, as shown by the ascending weight curve (Fig. 2), the conservation of fat stores, more moderate late hyperglycemia, and higher levels of IRI in serum and pancreas (Table I). The initial hypoglycemia was less pronounced with $35 \mathrm{mg} / \mathrm{kg}$ (Table I), despite significant elevation of serum IRI. Later, hyperglycemia was still definite but remained mild and associated with levels of serum IRI greater than in the fasting state, but still lower than might have been expected from the blood glucose levels. At that dose, for the first time, spontaneous recovery from the diabetic state was observed in about one-fourth of the animals with normalization of urine volume and little or no glycosuria. There was good correlation between the observed recovery and the pancreatic IRI content, which was regularly greater in the animals which had recovered than in the persistently diabetic animals.

The injection of $25 \mathrm{mg} / \mathrm{kg}$ (Table I) was followed by slight, transient glycosuria. Otherwise, the measured indices were not grossly abnormal, except for a small but significant decrease in the pancreatic IRI content after $24 \mathrm{hr}$ and again after 7 days $(P<0.005)$. The weight curve of the injected animals was similar to that of noninjected controls. However, the effect of a second dose of $25 \mathrm{mg} / \mathrm{kg}, 3$ days after the first one, was striking in the sense that a severe diabetes appeared within $24 \mathrm{hr}$,

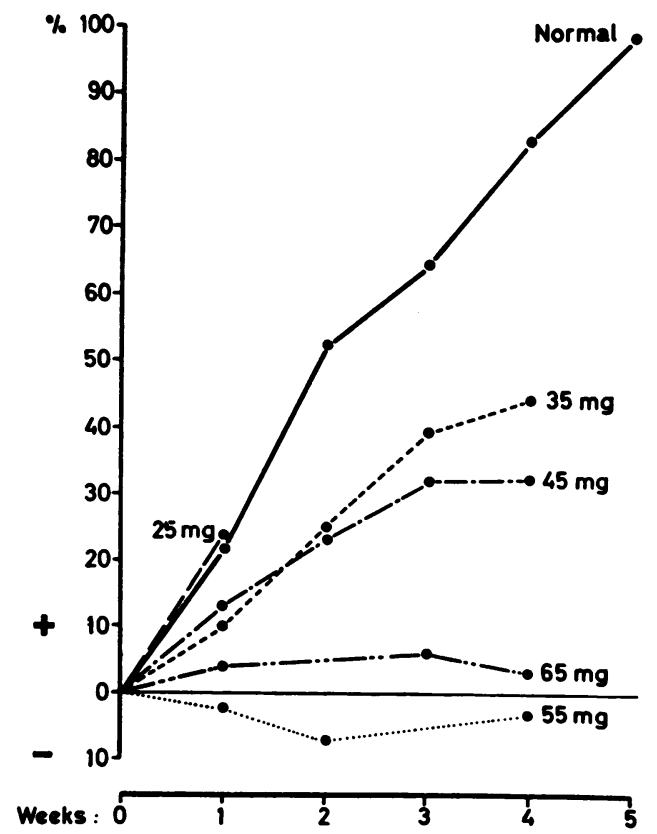

FigURE 2 Weight curves of streptozotocin-treated animals, in percentage change from initial weight.

Diabetogenic Action of Streptozotocin 
TABLE II

Effects of a Second Intravenous Injection of $25 \mathrm{mg} / \mathrm{kg}$ Streptozotocin, 3 Days after the First Injection, in Rats Fasted $16 \mathrm{hr}$ (Mean 士SEM)

\begin{tabular}{|c|c|c|c|c|}
\hline & \multirow[b]{2}{*}{$\begin{array}{c}\text { No. of } \\
\text { animals }\end{array}$} & \multicolumn{2}{|c|}{ Serum glucose } & \multirow[t]{2}{*}{ Pancreatic IR I } \\
\hline & & $\begin{array}{c}\text { Fasted } \\
\text { rats }\end{array}$ & $\begin{array}{l}\text { Nonfasted } \\
\text { rats }\end{array}$ & \\
\hline & & \multicolumn{2}{|c|}{$m g / 100 \mathrm{ml}$} & $m U / m g$ \\
\hline Before 1st injection & 17 & \multicolumn{2}{|c|}{$77.7 \pm 4$} & $1.85 \pm 0.08$ \\
\hline Before 2nd injection & 6 & \multicolumn{2}{|l|}{$105.8 \pm 16$} & \\
\hline $24 \mathrm{hr}$ after 1 st injection & 6 & \multicolumn{3}{|c|}{$150 \pm 4$} \\
\hline $24 \mathrm{hr}$ after $2 \mathrm{nd}$ injection & 9 & \multicolumn{3}{|c|}{$428 \pm 7 *$} \\
\hline 7 days after 1 st injection & 12 & $111.8 \pm 6$ & & $1.38 \pm 0.13$ \\
\hline 7 days after 2 nd injection & 10 & $224.9 \pm 30$ & & $0.23 \pm 0.14^{*}$ \\
\hline
\end{tabular}

* Significantly different from value after 1st injection $(P<0.001)$.

$\ddagger$ Significantly different from value after 1 st injection $(P<0.02)$.

with gross glycosuria and hyperglycemia (Table II). 7 days after the second injection, the pancreatic IRI content was $0.023 \mathrm{mU} / \mathrm{mg}$ pancreas, a value located on the dose-response curve between those found with 45 and $55 \mathrm{mg} / \mathrm{kg}$ (Fig. 3).

The pancreatic IRI content, $24 \mathrm{hr}$ after the injection of any dose of streptozotocin, was, as a rule, similar to that seen after 7 days (Table I) ; in no case was the difference between the 1- and 7-day values significant for the number of measurements made. After 28 days, however, there was a tendency toward a further decrease in the pancreatic insulin content for doses greater than $35 \mathrm{mg} /$ $\mathrm{kg}$, although the difference was statistically significant only for the dose of $65 \mathrm{mg} / \mathrm{kg}(P<0.05)$. The clear-cut relationship between the pancreatic IRI content after 24 $\mathrm{hr}$ and the dose of streptozotocin is shown in Fig. 3, which also shows that the curve obtained was quite similar when the pancreatic IRI content found after 7 and after 28 days was used. Furthermore, a comparable sigmoid curve resulted when the dose of streptozotocin (on a $\log$ scale) was related to the amount of IRI removed from the pancreas rather than to the amount remaining. The latter relationship best describes the pharmacologic effect of the drug in producing loss of pancreatic insulin and is, therefore, also shown (Fig. 4), even though the quantitative expression apparently most suited for comparative measurements is that shown in Fig. 3.

The quantitative relationship existing between the streptozotocin dose (on a log scale) and the serum glucose level after a $16 \mathrm{hr}$ fast, 1,7 , and 28 days after the administration of streptozotocin, is illustrated in Fig. 5. Again the relationship is sigmoid in shape and, at the $24 \mathrm{hr}$ interval, quite steep in the $25-55 \mathrm{mg} / \mathrm{kg}$ range. That the variability of this response should be greater than that seen for the pancreatic IRI content is not surprising, since the serum glucose response is likely to be less directly related to the action of streptozotocin than the direct beta-cytotoxic effect.

Since varying the dose of streptozotocin apparently does permit the production of graded states of over-all pancreatic insulin depletion (Figs. 3 and 4), it was of

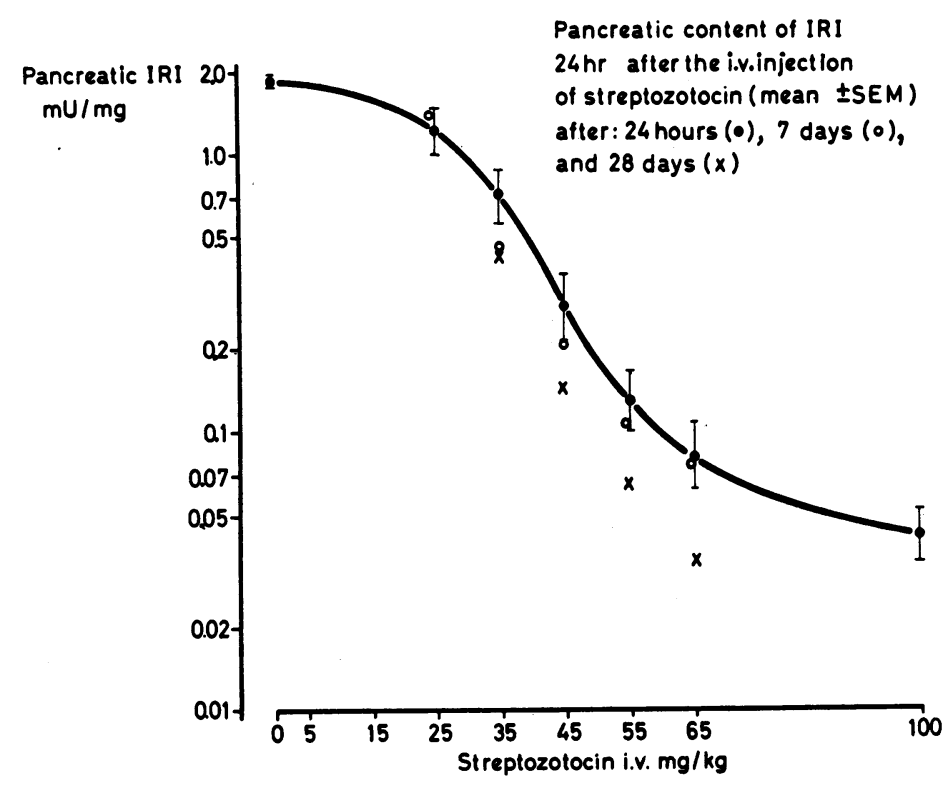

FIGURE 3 Relationship between pancreatic IRI content, plotted on a $\log$ scale, and the dose of streptozotocin, $24 \mathrm{hr}(\bullet), 7$ days $(O)$, and 28 days $(X)$ after its intravenous injection. (Means and, for the 24-hr values, 2 SEM are shown.) 
evident interest to observe the relationship existing between pancreatic IRI content and such indices of the severity of the diabetic state as hyperglycemia and glycosuria. Figs. 6 and 7 demonstrate significant negative correlations $(P<0.01)$, at least for pancreatic IRI contents below $1 \mathrm{mU} / \mathrm{mg}$ pancreas. For lesser losses of pancreatic IRI content, as seen with streptozotocin doses between 20 and $35 \mathrm{mg} / \mathrm{kg}$, the response of a more sensitive index of the diabetic state was investigated by using glucose tolerance conditions, as shown in Fig. 8 and Table III.

When compared with identically treated control rats, the intragastric administration of $3 \mathrm{~g} / \mathrm{kg}$ glucose, 7 days after the intravenous injection of $20 \mathrm{mg} / \mathrm{kg}$ streptozotocin, did not result in significant deviations of plasma glucose and IRI responses. After reduction of the pancreatic IRI content by one-third through the intravenous injection of $25 \mathrm{mg} / \mathrm{kg}$ streptozotocin, however, plasma glucose levels were elevated after 30 and $60 \mathrm{~min}(P<$ 0.05 and $P<0.01$ ), while the corresponding increase of plasma IRI was both less marked and delayed $(P<$ 0.05 for $30 \mathrm{~min}$ values). The injection of $35 \mathrm{mg} / \mathrm{kg}$, resulting in the loss of nearly four-fifths of the pancreatic IRI content, was associated with gross intolerance to glucose, with rather flat and depressed plasma IRI response. The relationship between plasma IRI and plasma glucose in the animals treated with $25 \mathrm{mg} / \mathrm{kg}$ streptozotocin was analyzed further and compared with the same relationship in the untreated control animals, as shown in Fig. 9. The slope of the regression line relating plasma

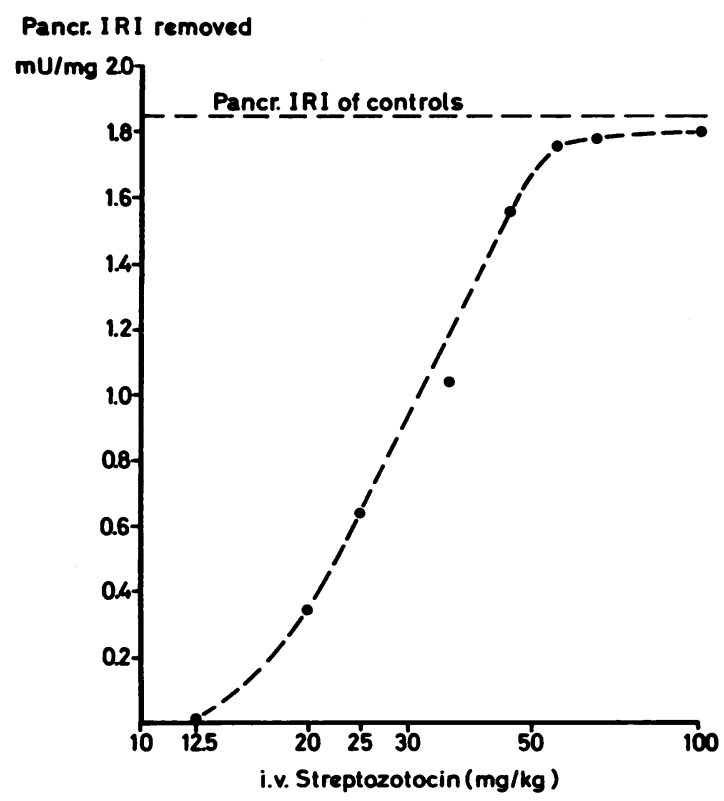

Figure 4 Relationship between the amount of pancreatic (Pancr.) IRI removed from the pancreas and the dose of streptozotocin plotted on a $\log$ scale.

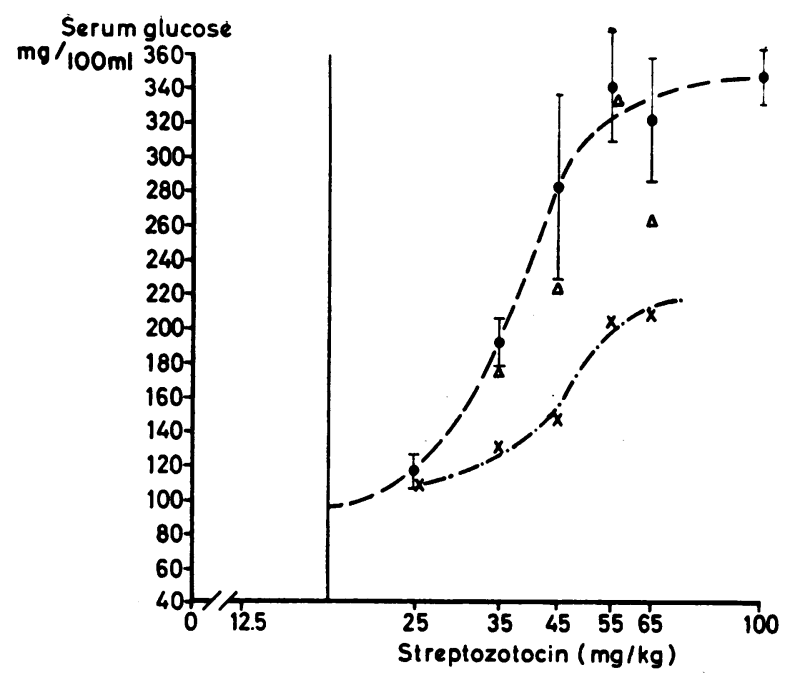

FIGURE 5 Relationship between the dose of streptozotocin (plotted on a log scale) and the serum glucose level, 24 hr $(\bullet), 7$ days $(X)$, and 28 days $(\triangle)$ after the intravenous injection of streptozotocin. (Means and, for the $24 \mathrm{hr}$ values, 2 SEM are shown.)

IRI to plasma glucose levels obtained at 0 and $30 \mathrm{~min}$ after the administration of glucose to the streptozotocintreated animals was significantly less than for the corresponding intervals after glucose administration to untreated control animals. On the other hand, there was

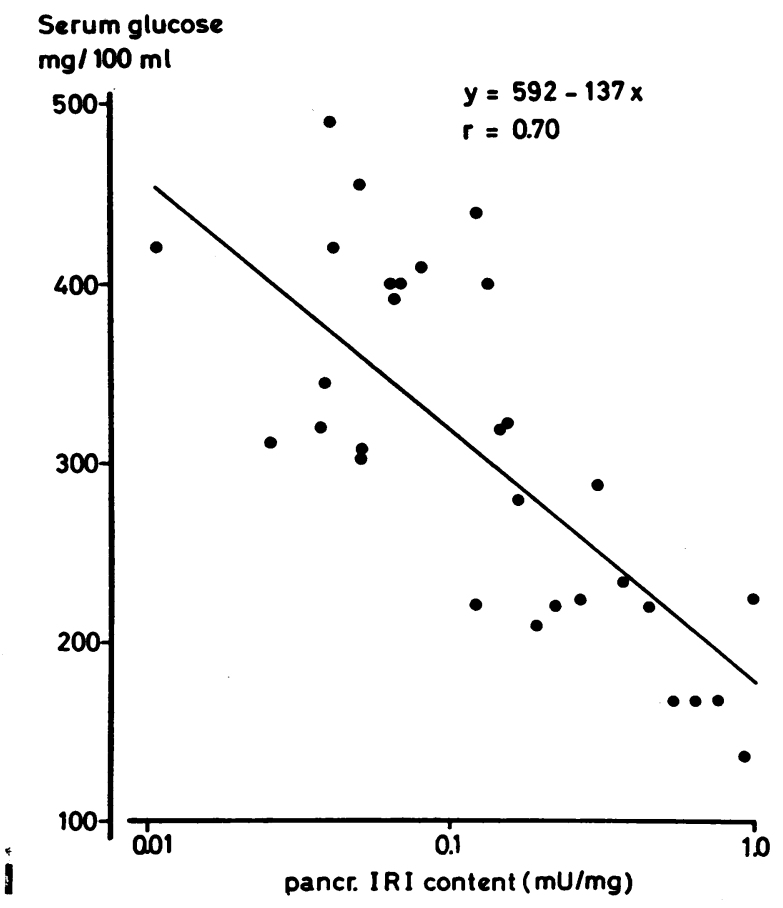

FIGURE 6 Relationship between serum glucose levels and the pancreatic IRI content (plotted on a log scale), $24 \mathrm{hr}$ after the intravenous injection of streptozotocin.

Diabetogenic Action of Streptozotocin 
no such difference when the values considered were those obtained 2 and $4 \mathrm{hr}$ after the glucose load. It is evident from these data that the insulinogenic response calculated according to Seltzer, Allen, Herron, and Brennan (11) also decreased in the animals injected with $25 \mathrm{mg} / \mathrm{kg}$ streptozotocin $1 \mathrm{wk}$ previously.

The intraperitoneal injection of nicotinamide before the intravenous injection of streptozotocin prevented the occurrence of diabetes; the effectiveness of the prevention related to the dose of nicotinamide and to that of streptozotocin, as well as to the interval between the two injections, as shown in Table IV. It may be noted that some protection was still present when nicotinamide was administered as long as $6 \mathrm{hr}$ before streptozotocin. On the other hand, some degree of hyperglycemia was present $24 \mathrm{hr}$ after streptozotocin even in those animals where frank diabetes and pancreatic insulin loss were prevented by nicotinamide. Finally, it is noteworthy that $\mathrm{D}$-glucosamine, given either intravenously $(180 \mathrm{mg} / \mathrm{kg})$ or intraperitoneally $(4 \mathrm{~g} / \mathrm{kg})$, did not appear to interfere with the beta-cytotoxic action of streptozotocin. (Pancreatic IRI content, $24 \mathrm{hr}$ after streptozotocin, $65 \mathrm{mg} / \mathrm{kg}$, administered together with $\mathrm{D}$-glucosamine, was $0.18 \mathrm{mU} / \mathrm{mg}$, as compared with $0.09 \mathrm{mU} /$ $\mathrm{mg}$ for streptozotocin alone.)

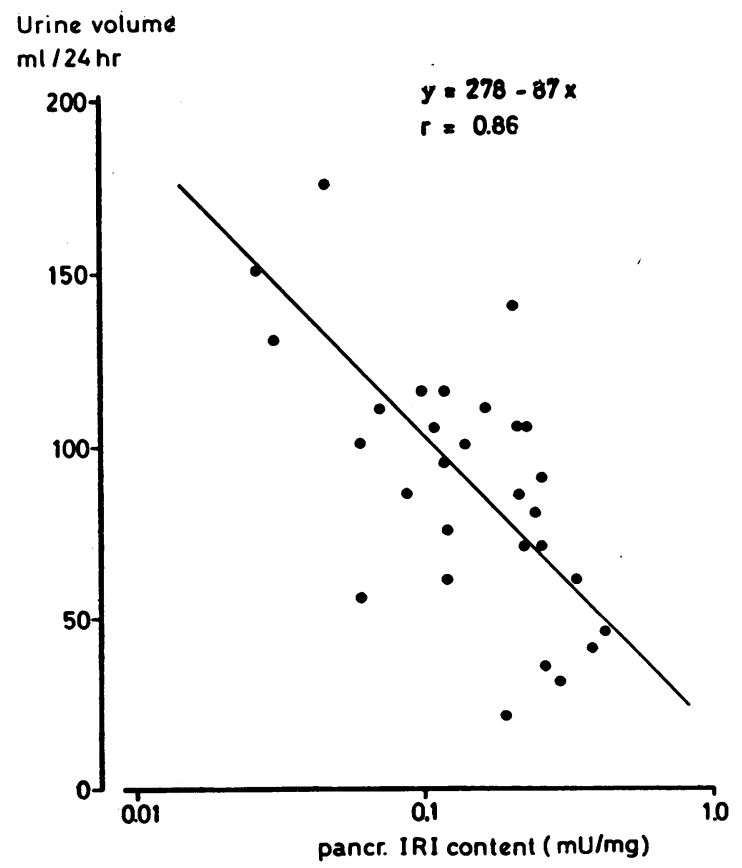

FigURE 7 Relationship between the urine volume of the 6th day after the intravenous injection of streptozotocin and the pancreatic IRI content (plotted on a log scale) measured $24 \mathrm{hr}$ later.

TABLE III

Gastric Glucose Tolerance Test in Control Rats and in Rats Injected with Various Intravenous Doses of Streptozotocin 1 Wk before the Test (Mean \pm SEM)

\begin{tabular}{|c|c|c|c|c|c|c|c|c|c|}
\hline \multirow[b]{2}{*}{$\begin{array}{c}\text { Dose of } \\
\text { streptozotocin }\end{array}$} & \multirow[b]{2}{*}{$\begin{array}{l}\text { No. of } \\
\text { animals }\end{array}$} & \multirow[b]{2}{*}{ Weight } & \multirow{2}{*}{$\begin{array}{l}\text { Pancreatic IRI } \\
\text { content }\end{array}$} & & \multicolumn{5}{|c|}{$\min$} \\
\hline & & & & & $\mathbf{0}$ & 30 & 60 & 120 & 240 \\
\hline \multirow{3}{*}{0} & \multirow{3}{*}{11} & $g$ & $m U / m g$ & & & & & & \\
\hline & & \multirow[t]{2}{*}{$\begin{array}{c}196 \\
( \pm 3)\end{array}$} & \multirow[t]{2}{*}{$\begin{array}{c}1.8 \\
( \pm 0.2)\end{array}$} & Plasma glucose, $m g / 100 m l$ & $\begin{array}{l}114.3 \\
( \pm 3.2)\end{array}$ & $\begin{array}{c}225.9 \\
( \pm 8.9)\end{array}$ & $\begin{array}{c}211 \\
( \pm 6)\end{array}$ & $\begin{array}{c}145 \\
( \pm 10)\end{array}$ & $\begin{array}{l}140 \\
( \pm 3)\end{array}$ \\
\hline & & & & Plasma IRI, $\mu U / m l$ & $\begin{array}{c}41.3 \\
( \pm 4.1)\end{array}$ & $\begin{array}{r}95.5 \\
( \pm 10.8)\end{array}$ & $\begin{array}{c}70.8 \\
( \pm 8.1)\end{array}$ & $\begin{array}{c}47 \\
( \pm 4.5)\end{array}$ & $\begin{array}{c}42.8 \\
( \pm 4.9)\end{array}$ \\
\hline \multirow[t]{2}{*}{$20 \mathrm{mg} / \mathrm{kg}$} & \multirow[t]{2}{*}{8} & \multirow[t]{2}{*}{$\begin{array}{l}193 \\
( \pm 5.3)\end{array}$} & \multirow[t]{2}{*}{$\begin{array}{r}1.44 \\
( \pm 0.1)\end{array}$} & Plasma glucose, $m g / 100 m l$ & $\begin{array}{l}116.0 \\
( \pm 4.2)\end{array}$ & $\begin{array}{l}221.5 \\
( \pm 2.6)\end{array}$ & $\begin{array}{l}212.9 \\
( \pm 5.1)\end{array}$ & $\begin{array}{l}141.5 \\
( \pm 6.9)\end{array}$ & $\begin{array}{l}148.5 \\
( \pm 5.1)\end{array}$ \\
\hline & & & & Plasma IRI, $\mu U / m l$ & $\begin{array}{c}30 \\
( \pm 5.3)\end{array}$ & $\begin{array}{r}64.5 \\
( \pm 10.8)\end{array}$ & $\begin{array}{c}52 \\
( \pm 8.8)\end{array}$ & $\begin{array}{c}37.9 \\
( \pm 4.4)\end{array}$ & $\begin{array}{r}34.5 \\
( \pm 6.2)\end{array}$ \\
\hline \multirow[t]{2}{*}{$25 \mathrm{mg} / \mathrm{kg}$} & \multirow[t]{2}{*}{9} & \multirow[t]{2}{*}{$\begin{array}{c}201.1 \\
( \pm 2.7)\end{array}$} & \multirow[t]{2}{*}{$\begin{array}{r}1.06^{*} \\
( \pm 0.08)\end{array}$} & Plasma glucose, $\mathrm{mg} / 100 \mathrm{ml}$ & $\begin{array}{c}93 \\
( \pm 6.6)\end{array}$ & $\begin{array}{c}261 \ddagger \\
( \pm 14.6)\end{array}$ & $\begin{array}{r}279.6 \ddagger \\
( \pm 9.5)\end{array}$ & $\begin{array}{l}125.1 \\
( \pm 6.2)\end{array}$ & $\begin{array}{l}129.4 \\
( \pm 4.2)\end{array}$ \\
\hline & & & & Plasma IRI, $\mu U / m l$ & $\begin{array}{c}36.6 \\
( \pm 2.9)\end{array}$ & $\begin{array}{c}59 \ddagger \\
( \pm 6.6)\end{array}$ & $\begin{array}{c}61.3 \\
( \pm 5.7)\end{array}$ & $\begin{array}{c}43.7 \\
( \pm 3.9)\end{array}$ & $\begin{array}{r}47.9 \\
( \pm 5.3)\end{array}$ \\
\hline \multirow[t]{2}{*}{$35 \mathrm{mg} / \mathrm{kg}$} & \multirow[t]{2}{*}{5} & \multirow[t]{2}{*}{$\begin{array}{l}195 \\
( \pm 7)\end{array}$} & \multirow[t]{2}{*}{$\begin{array}{r}0.35^{*} \\
( \pm 0.06)\end{array}$} & Plasma glucose, $\mathrm{mg} / 100 \mathrm{ml}$ & $\begin{array}{c}112.2 \\
( \pm 10)\end{array}$ & $\begin{array}{l}419.2^{*} \\
( \pm 44)\end{array}$ & $\begin{array}{c}469.4^{*} \\
( \pm 45)\end{array}$ & $\begin{array}{l}301.8^{*} \\
( \pm 21)\end{array}$ & $\begin{array}{c}169.2 \\
( \pm 26.6)\end{array}$ \\
\hline & & & & Plasma IRI, $\mu U / m l$ & $\begin{array}{c}51.2 \\
( \pm 3.2)\end{array}$ & $\begin{array}{c}65.4 \\
( \pm 3.7)\end{array}$ & $\begin{array}{c}65.4 \\
( \pm 5.1)\end{array}$ & $\begin{array}{c}63.8 \\
( \pm 5.1)\end{array}$ & $\begin{array}{c}57 \\
( \pm 1.2)\end{array}$ \\
\hline
\end{tabular}

* Significantly different from control values $(P<0.01)$.

‡ Significantly different from control values $(P<0.05)$. 


\section{DISCUSSION}

The acute response to streptozotocin, as best seen in the triphasic blood glucose curve (Fig. 1), is remarkably similar to that observed after the intravenous administration of alloxan (12). Since the early hyperglycemia which follows alloxan has been attributed to an adrenaline response (13), it is reasonable to consider a similar explanation for streptozotocin, although this interpretation has not as yet been tested experimentally. The hypoglycemic phase has been attributed, in the case of alloxan, to the release of insulin from necrotizing pancreatic $\beta$-cells, although elevated serum insulin levels have been reported only very recently $(14,15)$. For streptozotocin, the insulin-induced nature of the hypo- glycemic phase is fully established by the results shown in Fig. 1 and Table I. Since there was no significant decrease in the pancreatic IRI content at that time, and since $\beta$-granules still seemed rather well preserved, both when examined histochemically (aldehyde-thionine) and when examined with the electron microscope (1), it is possible that soluble, "nongranular" insulin was released first. Later, concomitant with the precipitous fall in pancreatic IRI content, the numerous macrophages seen histologically may have been the primary agents responsible for disposal of the remaining insulin, without continuing release of IRI into the circulation and without continuing hypoglycemia. It is noteworthy that the early hyperglycemic phase was not associated with

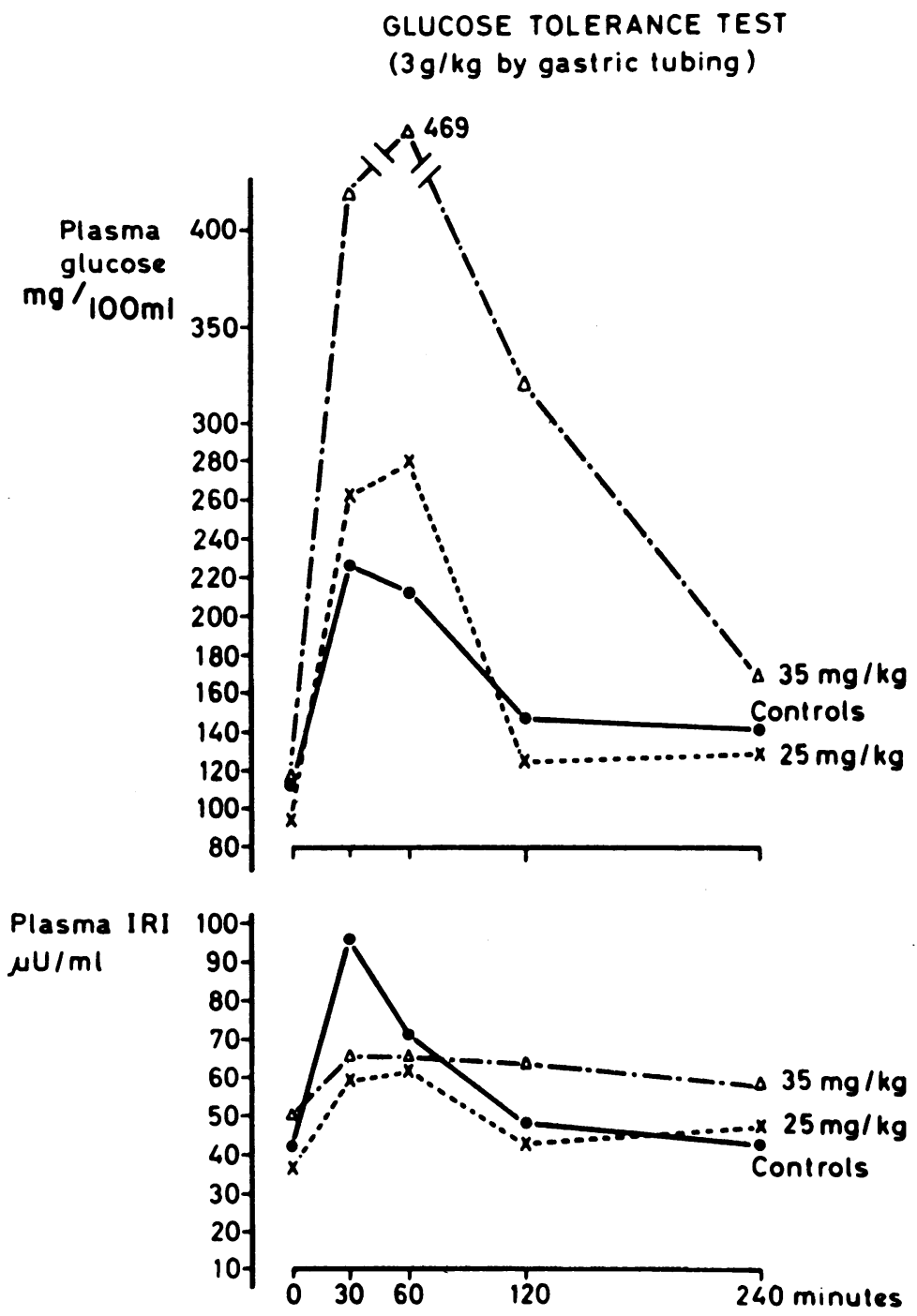

Figure 8 Glucose tolerance tests ( $3 \mathrm{~g}$ glucose/kg body weight by gastric tube) in animals having previously received 25 or $35 \mathrm{mg} / \mathrm{kg}$ streptozotocin intravenously and in control animals. 


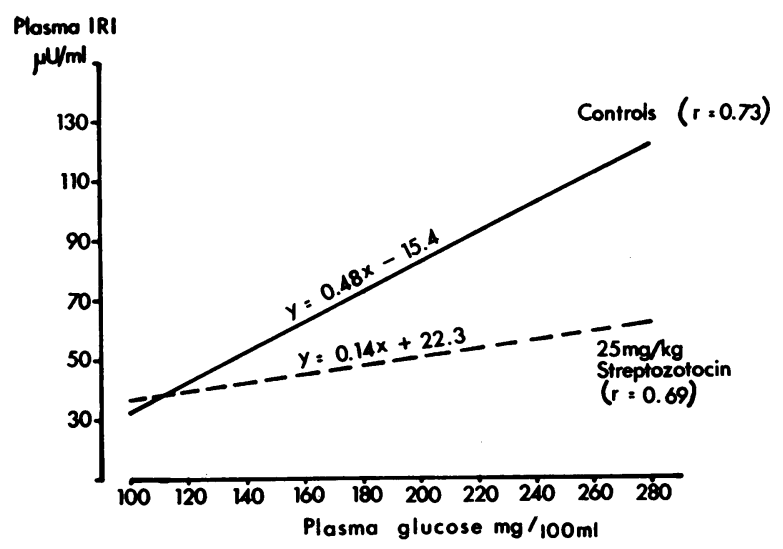

FIGURE 9 Relationship between plasma insulin and plasma glucose levels obtained 0 and $30 \mathrm{~min}$ after glucose administration in animals having received $25 \mathrm{mg} / \mathrm{kg}$ streptozotocin 7 days previously and in control animals.

a parallel increase in serum IRI levels, possibly as a result of either inhibition of insulin secretion by catecholamines released at that time (16) or of a direct effect of streptozotocin itself on the $\beta$-cells, as suggested by Creutzfeldt from his in vitro studies (17).

Frank diabetes was present from $24 \mathrm{hr}$ on, and the severity of the diabetic state was clearly related to the dose of streptozotocin administered. Since the occurrence of ketonuria in streptozotocin-induced diabetes has been questioned, it should be stressed that, after the intravenous administration of $100 \mathrm{mg} / \mathrm{kg}$, severe ketonuria was present as early as $24 \mathrm{hr}$ after injection, and death followed within 2-3 days unless insulin treatment was begun. In these animals, serum IRI levels after 24 $\mathrm{hr}$ were decreased by more than half below the normal fasting level, although measurable amounts of IRI were found in all instances. The absence of ketosis in animals having received intravenous streptozotocin doses of 65 $\mathrm{mg} / \mathrm{kg}$ or less is adequately explained by incomplete, although marked, insulin depletion, serum IRI levels persisting in the range of $20 \mu \mathrm{U} / \mathrm{ml}$, i.e., in the normal fasting range. Although accelerated mobilization of stored fat was evident, since visible fat stores disappeared within a few days, the rate of this mobilization was apparently such that it could be handled without the production of pronounced ketosis. It does not seem likely that this represents an unusual feature of streptozotocin-induced diabetes, as suggested by Mansford and Opie (18), but rather a predictable consequence of the incomplete insulin deficiency induced. Thus the results reported by these authors most likely compare apparently noncomparable entities, since the data in alloxan diabetes were obtained 2-3 days after the administration of alloxan, while those in streptozotocininjected animals were obtained after $1 \mathrm{wk}$. No measurements were made to ensure that a comparable degree of insulin depletion was achieved with both agents. Although additional studies will of course be needed to establish definitively whether metabolic anomalies in all tissues are similar in streptozotocin-injected animals and in animals with the same degree of insulin deficiency induced by any other means, our results to date lead us to conclude that the main, perhaps the only primary cause of abnormal metabolism in streptozotocin-injected animals is insulin deficiency of varying severity related to dosage. Evidently, the acute, early phase of the streptozotocin response, up to and including the first few days, is better excluded from this generalization.

TABLE IV

The Protective Action of the Intraperitoneal Administration of Nicotinamide before the Intravenous Injection of Streptozotocin

\begin{tabular}{cccccc}
\hline $\begin{array}{c}\text { Dose of } \\
\text { nicotinamide }\end{array}$ & $\begin{array}{c}\text { Dose of } \\
\text { streptozotocin }\end{array}$ & $\begin{array}{c}\text { Interval between } \\
\text { the injections }\end{array}$ & Serum glucose & Serum IRI & Pancreas IRI \\
\hline$m g / k g$ & $m g / k g$ & $m i n$ & $m g / 100 m l$ & $\mu U / m l$ & $m U / m g$ \\
0 & 65 & & $343.5 \pm 37$ & $21.5 \pm 2.0$ & $0.09 \pm 0.02$ \\
500 & 65 & 10 & $159.5 \pm 10.5$ & $68.5 \pm 13.2$ & $1.82 \pm 0.26$ \\
& & 30 & $147.5 \pm 7.3$ & $59.3 \pm 7.5$ & $2.1 \pm 0.24$ \\
& & 120 & $165 \pm 2$ & $66.3 \pm 7.7$ & $1.55 \pm 0.22$ \\
250 & & 360 & $216.3 \pm 10.7$ & $44.3 \pm 7$ & $1.48 \pm 0.28$ \\
125 & 65 & 10 & $338 \pm 27$ & $15.5 \pm 1$ & $0.12 \pm 0.01$ \\
62.5 & 65 & 10 & $142.5 \pm 2$ & $39.5 \pm 9$ & $1.82 \pm 0.21$ \\
0 & 65 & 10 & $149.5 \pm 8.5$ & $35 \pm 2.3$ & $1.1 \pm 0.13$ \\
125 & 45 & & $295.3 \pm 58.8$ & $23.3 \pm 2.7$ & $0.58 \pm 0.10$ \\
62.5 & 45 & 10 & $281 \pm 55$ & $38.4 \pm 2.2$ & $0.29 \pm 0.08$ \\
& 45 & 10 & $168.7 \pm 17.6$ & $26.9 \pm 3.3$ & $1.29 \pm 0.07$
\end{tabular}

Rats, by groups of from 4 to 6 , were sacrificed $24 \mathrm{hr}$ after the injection of streptozotocin. Values after $16 \mathrm{hr}$ fasting (mean \pm SEM). 
Spontaneous recoveries were noted after the injection of $35 \mathrm{mg} / \mathrm{kg}$ streptozotocin and, very occasionally, several weeks or months after the injection of streptozotocin doses as high as $45 \mathrm{mg} / \mathrm{kg}$. The possible presence of longer lasting noxious effects of streptozotocin at the level of even those $\beta$-cells which do survive the first insult is suggested by the apparent cumulative action of two $25 \mathrm{mg} / \mathrm{kg}$ doses of streptozotocin administered 3 days apart. The first dose resulted in a decrease in pancreatic IRI content from 1.8 to $1.2 \mathrm{mU} /$ $\mathrm{mg}$, without fasting hyperglycemia, while the second dose was followed by severe diabetes within $24 \mathrm{hr}$ and a further decrease in the pancreatic IRI content to $0.23 \mathrm{mU} / \mathrm{mg}$. This was an unexpected observation and one without parallel in previous experience with alloxan. Although the administration of subdiabetogenic doses of alloxan repeatedly over many days has been reported to lead to decreasing glucose tolerance in a few instances (19), a decreased response to successive doses has been the more general experience $(20,21)$. The cumulative effect noted with streptozotocin might be the result of fixation of the drug within $\beta$-cells, a toxic level being reached after additional fixation following the second dose. The chemical lability of streptozotocin at neutral $\mathrm{pH}$, however, makes this an unlikely explanation, whereas alteration of $\beta$-cell metabolism by the first dose with resulting increased sensitivity to the second dose is a more attractive interpretation, and one that correlates with morphological evidence suggesting that the second dose is indeed more damaging than the first one. ${ }^{1}$ A conclusive interpretation of this surprising finding, however, will have to await studies with radioactively labeled streptozotocin, when it becomes available.

Several relationships between the dose of streptozotocin administered and its metabolic effects have been explored in the present study and have revealed a remarkably reproducible and close relationship with pancreatic IRI content (Figs. 3 and 4). This suggests, although it does not establish, that the insulin-producing $\beta$-cell is the primary target of streptozotocin action. Furthermore, the quantitative relationship was quite similar whether pancreatic IRI was measured at 24 hr, after 7 days, or after 28 days, with little if any tendency for subsequent regeneration of capacity for insulin storage. Absence of recovery of pancreatic IRI content associated with persistently low yet significant serum IRI levels indicates continued synthesis with immediate release of insulin in the presence of hyperglycemia, an interpretation entirely consistent with the morphological finding of small numbers of surviving $\beta$-cells (1). The generally lower pancreatic IRI content after 28 days, when compared with $24 \mathrm{hr}$ and 7 days, significant for the $65 \mathrm{mg} / \mathrm{kg}$ dose $(P<0.05)$ and of borderline significance for the $55 \mathrm{mg} / \mathrm{kg}$ dose $(P<0.1)$, may reflect the possibly deleterious effect of persistent hyperglycemia.

Additional quantitative relationships which have been examined were: $(a)$ that between the streptozotocin dose and either fasting blood glucose level or 24-hr urine volume, after stabilization of the diabetic state, and $(b)$ that between pancreatic IRI content and the same two indices of the diabetic state. It is noteworthy that the fasting serum glucose value reached for any given streptozotocin dose 7 days after its administration was less than that reached after $24 \mathrm{hr}$ or after 28 days (Fig. 5). It is likely that the higher values after $24 \mathrm{hr}$ resulted from factors associated with the acute response phase, while the more pronounced hyperglycemia 28 days after streptozotocin administration correlates with the further decrease in pancreatic IRI content. The greater variability of metabolic indices as a measure of pancreatic insulin depletion is clearly seen in the considerable scatter of the points relating pancreatic IRI content to either fasting blood glucose or to urine volume during the $24 \mathrm{hr}$ preceding the sacrifice of the animals for obtaining pancreatic tissue (Figs. 6 and 7). It is equally striking, however, that the correlation was, in either instance, a clearly significant one $(P<0.01)$ and that the slopes of the regression lines indicate that fasting hyperglycemia becomes abnormal when pancreatic IRI content drops below $1.0 \mathrm{mU} / \mathrm{mg}$, and urine volume clearly increases when pancreatic IRI content drops below 0.4 $\mathrm{mU} / \mathrm{mg}$.

Analysis of the several quantitative correlations just described clearly leads to the conclusion that the best index of the diabetogenic activity of streptozotocin is the pancreatic IRI content $24 \mathrm{hr}$ after intravenous administration of the drug (Fig. 3 ). Such a precise quantitative evaluation of diabetogenic activity is desirable not only for comparing different diabetogenic agents or modifications in the chemical structure of substances such as streptozotocin, but also for quantitatively satisfactory scrutiny of agents or measures which might modify diabetogenicity. As an example, we have analyzed more precisely the reported activity of nicotinamide in preventing the diabetagenic action of streptozotocin (5). The data in Table IV demonstrate that the measurement of pancreatic IRI content, $24 \mathrm{hr}$ after streptozotocin, with and without pretreatment with nicotinamide (which does not affect by itself pancreatic or serum IRI [22]) at varying times and in varying amounts, describes the relationship between the beta-cytotoxic agent and its inhibitor much better than simple analysis as to presence or absence of diabetic metabolic anomalies. Indeed, it is to be noted that even when nicotinamide prevented the occurrence of streptozotocin-induced diabetes or pancreatic IRI depletion, it did not prevent some degree of hyperglycemia $24 \mathrm{hr}$ after the injection of the drug. 
This again suggests, as discussed above (Fig. 5), that the hyperglycemia seen $24 \mathrm{hr}$ after streptozotocin is not exclusively the result of insulin depletion and, furthermore, that nicotinamide does not prevent all actions of streptozotocin, as also demonstrated by the report that the antitumoral activity of streptozotocin is not abolished by nicotinamide doses sufficient to prevent diabetes (5). Accordingly, it would not seem likely that nicotinamide directly inactivates streptozotocin in plasma, one of the mechanisms postulated by Lazarow for the protective action of nicotinamide administered before alloxan (23). Although nicotinamide protection has also been related to a suggested increase in diphosphopyridine nucleotide (NAD) within $\beta$-cells (5), as in hepatic tissue (24), this is but a hypothetic interpretation and, for the time being, the nature of this protective activity remains unknown.

The evidence derived from the administration of two doses of $25 \mathrm{mg} / \mathrm{kg}$ streptozotocin, with an interval of 3 days, suggested the occurrence of alterations of $\beta$-cells well before frank cytotoxicity and necrosis. Furthermore, while the regression lines shown in Figs. 6 and 7 suggested that frank diabetes only occurs whenever pancreatic IRI content drops below 25-35\% of normal, it was of interest to know whether an earlier diabetic anomaly would be detected if the index used were a more sensitive one than fasting hyperglycemia or glycosuria. The results of a careful reinvestigation of the low dose range indeed do suggest that the $25 \mathrm{mg} / \mathrm{kg}$ dose produced a metabolic state quite similar to that encountered in the so-called "chemical" phase of early diabetes in man. In the presence of moderate depression of pancreatic IRI content to $1.06 \mathrm{mU} / \mathrm{mg}$, fasting plasma glucose and urinary glucose levels were normal, while plasma glucose was elevated above the levels seen in controls at 30 and $60 \mathrm{~min}$ after the intragastric glucose load. Plasma IRI, on the other hand, was depressed below the control level at $30 \mathrm{~min}$ and continued to increase between 30 and $60 \mathrm{~min}$, suggesting the presence of delayed insulin response (Fig. 8 and Table III). The most significant demonstration of this anomaly is that shown in Fig. 9 which establishes that, 1 wk after the intravenous administration of a single $25 \mathrm{mg} / \mathrm{kg}$ streptozotocin dose, the slope of the regression line defining the relation between plasma IRI and plasma glucose during the first 30 min after glucose administration was statistically less $(0.14$ as against $0.48, P<0.001)$ than in similarly treated control animals. This last finding is entirely in keeping with the observations by Seltzer et al. (11) in nonobese diabetics, using his "insulinogenic index," while Colwell and Lein have observed qualitatively and quantitatively almost identical alterations in prediabetic patients (25). With slightly different techniques, Cerasi and Luft (26) as well as Ricketts, Cherry, and Kirsteins (27) similarly conclude to an early inadequacy of the insulin secretory response to glucose in prediabetics and in nonobese mild diabetics. This has again been confirmed by Perley and Kipnis (28) who also emphasize, as have several of the previously quoted workers, that by contrast in overweight subjects, both normal and diabetic, the insulin secretory response to glucose is often excessive, suggesting peripheral insulin antagonism which is as yet not fully defined.

It is of course recognized that any comparison between human diabetes and experimental diabetes in animals is hazardous, and no such direct comparison is suggested here. The experimental availability of a syndrome, however, which mimicks the particular feature of delayed insulin response to glucose loading now repeatedly observed in human prediabetes and early diabetes, may be of value in defining more closely the physiologic mechanism implicated in the production of such a delayed secretory response. Even now, it is of interest to know that the delayed response pattern was associated with a pancreatic IRI content decreased by one-third, a decrease probably related to the decrease in the number of $\beta$-cells, since visible signs of cellular necrosis are seen after this dose. An additional alteration of as yet nonnecrotic $\beta$-cells, however, is also likely, as suggested by the enhanced response to a second, identical dose, as previously discussed.

The diabetogenic activity of alloxan has been the subject of an excellent recent review (29), and it is evident that the diabetogenic activity of streptozotocin resembles that of alloxan in many ways, but it also differs from it by four main characteristics. Firstly, the selectivity of streptozotocin action on $\beta$-cells is very much greater, as best seen from the fact that a dose, $100 \mathrm{mg} / \mathrm{kg}$, three times that needed for the production of mild yet frank diabetes, still is primarily diabetogenic, only insulin treatment being required for the survival of these animals. Secondly, the relationship between dose of streptozotocin and diabetogenic response differs grossly from that of alloxan, the dosage range from mild to severe diabetogenic activity being very much broader; essentially complete diabetogenic activity being achieved with a dose approximately four times that leading to the first appearance of abnormal glucose tolerance. For intravenously administered alloxan, the dosage increment needed to go from mild to severe diabetogenic activity in adult rats is at best $20 \%$ and often reveals marked generalized toxicity as well. Thirdly, the administration of a first, subdiabetogenic dose of streptozotocin creates a new state leading to markedly increased diabetogenic activity of a second identical dose of the compound. This has never been convincingly reported for alloxan. Fourthly, although not shown in this report, the diabetogenic activity of streptozotocin is only little influenced by changes in the nutritional state, whereas major increases or decreases in sensitivity to alloxan are induced by fasting or feeding. Finally, it is worth men- 
tioning that streptozotocin is diabetogenic in the guinea pig, a species notably resistant to the diabetogenic action of alloxan (30).

These special features of the diabetogenic activity of streptozotocin suggest that it will prove to be an agent more reproducible in its use, more convenient, and hetter able to allow for the induction of a diabetic state of graded severity suitable for modulated endocrine and metabolic analysis, perhaps suitable as well for screening for new types of antidiabetic agents, such as truly insulin-like agents or agents which result in an increased pancreatic insulinogenic reserve.

Note Added in Proof. After this report was submitted for publication, Schein and Bates (1968 Diabetes 17: 760) reported that the early elevation in blood sugar after streptozotocin administration is independent of the adrenal gland. The suppression of the diabetogenic action of streptozotocin by nicotinamide was confirmed by these authors and, more recently, by Dulin and Wyse (1969 Diabetes 18: 459) who also reported a protective action of pyrazinamide and 2-deoxygiucose.

\section{ACKNOWLEDGMENTS}

The authors gratefully acknowledge the invaluable technical assistance of Mrs. Janine Bassi.

This work was supported in part by grants-in-aid from the Fonds National Suisse de la Recherche Scientifique, Berne, Switzerland (Grant Nos. 3618 and 4848.3).

\section{REFERENCES}

1. Junod, A., A. E. Lambert, L. Orci, R. Pictet, A. E. Gonet, and A. E. Renold. 1967. Studies of the diabetogenic action of streptozotocin. Proc. Soc. Exp. Biol. Med. 126: 201 .

2. Rakieten, N., M. L. Rakieten, and M. V. Nadkarni. 1963. Studies on the diabetogenic action of streptozotocin. Cancer Chemother. Rep. 29: 91.

3. Evans, J. S., G. C. Gerritsen, K. M. Mann, and S. P. Owen. 1965. Antitumor and hyperglycemic activity of streptozotocin (NSC-37917) and its cofactor, U-15.774. Cancer Chemother. Rep. 48: 1.

4. Arison, R. N., E. I. Ciaccio, M. S. Glitzer, A. B. Cassaro, and M. P. Pruss. 1967. Light and electron microscopy of lesions in rats rendered diabetic with streptozotocin. Diabetes. 16: 51.

5. Schein, P., D. Cooney, and L. Vernon. 1967. Protection against streptozotocin induced diabetes. Cancer Res. 27: 2324.

6. Herr, R. R., H. K. Jahnke, and A. D. Argoudelis. 1967. The structure of streptozotocin. J. Amer. Chem. Soc. 89: 4808 .

7. Scott, D. A., and A. M. Fisher. 1938. Studies on the pancreas and liver of normal and zinc-fed cats. Amer. J. Physiol. 121: 253.

8. Hyvärinen, A., and E. A. Nikkilä. 1962. Specific determination of blood glucose with O-Toluidine. Clin. Chim. Acta. 7: 140.

9. Hales, C. N., and P. J. Randle. 1963. Immunoassay of insulin with insulin-antibody precipitate. Biochem. J. 88: 137.

10. Morgan, C. R., and A. Lazarow. 1963. Immunoassay of insulin; two antibody system. Diabetes. 12: 115 .

11. Seltzer, H. S., E. W. Allen, A. L. Herron, Jr., and M. T. Brennan. 1967. Insulin secretion in response to glycemic stimulus: relation of delayed initial release to carbohydrate intolerance in mild diabetes mellitus. J. Clin. Invest. 46: 323 .

12. Dunn, J. S., and N. G. B. Mc Letchie. 1943. Experimental alloxan diabetes. Lancet. 2: 384.

13. Goldner, M. G., and G. Gomori. 1944. Studies on the mechanism of alloxan diabetes. Endocrinology. 35: 241.

14. Howell, S. L., and K. W. Taylor. 1967. The acute pancreatic effect of alloxan in the rabbit. J. Endocrinol. 37: 421.

15. Lundquist, I., and C. Rerup. 1967. On the development of alloxan diabetes in mice. Eur. J. Pharmacol. 2: 35.

16. Porte, D., Jr., A. Graber, T. Kuzuya, and R. H. Williams. 1966. The effect of epinephrine on immunoreactive insulin levels in man. J. Clin. Invest. 45: 228.

17. Creutzfeldt, W., H. Frerichs, and C. Creutzfeldt. 1969. The stimulation and inhibition of insulin secretion in vivo and in vitro. In Diabetes. J. Ostman, editor. Excerpta Medica Foundation, Publishers, Amsterdam. 110.

18. Mansford, K. R. L., and L. Opie. 1968. Comparison of metabolic abnormalities in diabetes mellitus induced by streptozotocin or by alloxan. Lancet. 1: 670 .

19. Shipley, E. G., and A. N. Rannefeld. 1945. Glucose tolerance in rats following repeated small doses of alloxan. Endocrinology. 37: 313.

20. Meade, R. C., and H. M. Klitgaard. 1960. Mechanism of alloxan diabetes inhibition by vasopressor drugs. Amer. J. Physiol. 199: 25.

21. Loubatières, A. 1948. Résistance à l'action diabétogène de l'alloxane chez le chien. $C$. R. Séances Soc. Biol. Filiales. 142: 145.

22. Stauffacher, W., I. Burr, A. Gutzeit, D. Beaven, J. Veleminsky, and A. E. Renold. 1969. Streptozotocindiabetes: time course of irreversible B-cell damage; further observations on prevention by nicotinamide. Proc. Soc. Exp. Biol. Med. In press.

23. Lazarow, A., J. Liambies, and A. J. Tausch. 1950. Protection against alloxan diabetes with nicotinanide. J. Lab. Clin. Med. 36: 249.

24. Kaplan, N. O., A. Goldin, S. R. Humphreys, M. M. Ciotti, and F. E. Stolzenbach. 1956. Pyridine nucleotide synthesis in the mouse. J. Biol. Chem. 219: 287.

25. Colwell, J. A., and A. Lein. 1967. Diminished insulin response to hyperglycemia in prediabetes and diabetes. Diabetes. 16: 560 .

26. Cerasi, E., and R. Luft. 1967. The plasma insulin response to glucose infusion in healthy subjects and in diabetes mellitus. Acta Endocrinol. 55: 278.

27. Ricketts, H. T., R. A. Cherry, and L. Kirsteins. 1966. Biochemical studies of "prediabetes." Diabetes. 15: 880.

28. Perley, M. J., and D. M. Kipnis. 1967. Plasma insulin response to oral and intravenous glucose: studies in nor$\mathrm{mal}$ and diabetic subjects. J. Clin. Invest. 46: 1954.

29. Webb, J. L. 1966. Enzyme and Metabolic Inhibitors. Academic Press Inc., New York. 3: 367.

30. Brodsky, G., and J. Logothetopoulos. 1968. Streptozotocin induced diabetes in the mouse and guinea-pig. Fed. Proc. 27: 547. (Abstr.) 